\title{
C-KIT Tyrosine Kinase Protein Overexpression
}

National Cancer Institute

\section{Source}

National Cancer Institute. C-KIT Tyrosine Kinase Protein Overexpression. NCI Thesaurus.

Code C39711.

A molecular abnormality indicating the presence of an abnormally high level of the mast/stem cell growth factor receptor Kit protein. 